\title{
Glycan Sequence-Dependent Nod2 Activation Investigated by Using a Chemically Synthesized Bacterial Peptidoglycan Fragment Library
}

\author{
Ning Wang, ${ }^{[a]}$ Cheng-yuan Huang, ${ }^{[a]}$ Mizuho Hasegawa, ${ }^{[b]}$ Naohiro Inohara, ${ }^{[b]}$ \\ Yukari Fujimoto, ${ }^{*[a]}$ and Koichi Fukase ${ }^{*[a]}$
}

\begin{abstract}
Nucleotide oligomerization domain-containing protein 2 (Nod2), an innate immune receptor, recognizes bacterial cellwall peptidoglycan (PGN), the minimum ligand of which is muramyl dipeptide (MDP). Enzymatic digestion of PGN appears to be important for Nod2 recognition. PGN is degraded by muramidase or glucosamidase through a process that produces two types of glycan sequence; glycans containing GlcNAc $\beta(1 \rightarrow 4)$ MurNAc or MurNAc $\beta(1 \rightarrow 4)$ GlcNAc. In this report, a range of disaccharide or tetrasaccharide fragments of
\end{abstract}

each sequence were chemically synthesized, and their activities in stimulating human Nod2 (hNod2) were investigated. The results reveal that hNod2 recognitions is dependent on the glycan sequence, as demonstrated by comparing the activities of glycans with the same peptide moieties. (MurNAc $\beta(1 \rightarrow$ 4) GlcNAc) ${ }_{2}$-containing structures exhibited stronger activity than those containing $(\operatorname{GlcNAc} \beta(1 \rightarrow 4) \text { MurNAc) })_{2}$. The results suggest that differences in the enzymatic degradation process affect the host's immunomodulation process.

\section{Introduction}

Innate immune receptors recognize a variety of microbial components, known as microbe-associated molecular patterns (MAMPs) or pathogen-associated molecular patterns (PAMPs), to activate the immune system. A variety of innate immune receptors, also known as pattern-recognition receptors (PRRs), have been identified, including Toll-like receptors (TLRs), Nodlike receptors (NLRs), RIG-like receptor (RLR) and C-type lectin receptor (CLR). Nucleotide oligomerization domain-containing proteins 1 and 2 (Nod1, Nod2), ${ }^{[1,2]}$ which are founding members of the NLR family, recognize peptidoglycan (PGN). ${ }^{[3-5]}$ PGN contains long glycan chains consisting of alternating $\mathrm{N}$-acetylglucosamine (GlcNAc) and $\mathrm{N}$-muramic acid (MurNAc) linked by a $\beta(1 \rightarrow 4)$ bond. The glycans are connected to one another through a peptide linkage at the carboxylic acid of MurNAc, outside the plasma membrane. In most bacteria, L-Ala- $\gamma$-D-Glu or L-Ala- $\gamma$-D-GluNH ${ }_{2}$ (L-Ala- $\gamma$-D-isoGIn) is connected to MurNAC, and the third amino acid connecting to the Glu (or $\mathrm{GluNH}_{2}$ ) is usually a diaminocarboxylic acid: L-Lys in many Gram-positive bacteria or meso-diaminopimelic acid in most Gram-negative bacteria or some Gram-positive bacteria. Our group has synthesized a variety of PGN fragment structures in an effort to search for structures recognized by the PGN receptors. ${ }^{[6]}$ This work has revealed the minimum ligand recognition structures of Nod1 and Nod2. ${ }^{[1,3]}$ Because Nod1 and Nod2 are cytosolic

[a] N. Wang, Dr. C.-y. Huang, Prof. Dr. Y. Fujimoto, Prof. Dr. K. Fukase Department of Chemistry, Graduate School of Science, Osaka University 1-1 Machikaneyama, Toyonaka, Osaka 560-0043 (Japan)

[b] Dr. M. Hasegawa, Prof. Dr. N. Inohara

Department of Pathology, University of Michigan Medical School 1150 W. Medical Center Dr., Ann Arbor, Michigan 48109 (USA)

Supporting information for this article is available on the WWW under http://dx.doi.org/10.1002/cbic.201200655. proteins and both proteins prefer smaller ligands rather than PGN itself, ${ }^{[1-4]}$ enzymatic digestion of PGN, followed by ligand transport appears to be critical for Nod1 and Nod2 recognition. NOD2 mutations are associated with a susceptibility to inflammatory diseases, including early-onset sarcoidosis (EOS), Blau syndrome (BS), and Crohn's disease (CD). ${ }^{[7-9]}$

Our previous studies revealed that Nod2 recognizes a muramyl dipeptide (MDP, MurNAc-L-Ala- $\gamma$-D-isoGln) as the minimum ligand structure and also recognizes peptidoglycan fragments containing MDP. MDP showed the most potent Nod2stimulating activity, and the activity decreased as the glycan and peptide chain lengths increased ${ }^{[6,10-13]}$ In these studies, we synthesized tetrasaccharide and octasaccharide fragments that contained the GlcNAc-MurNAc unit. In host organisms, sequences containing the GlcNAc-MurNAc unit are produced by lysozyme, also known as muramidase, which cleaves $\beta(1 \rightarrow 4)$ linkages between $N$-acetylmuramic acid and $N$-acetyl-D-glucosamine residues in PGN.

Various PGN fragments are released from bacteria during bacterial cell lysis. These fragments are produced by bacterial muramidase and glucosamidase and, therefore, contain two glycan sequences: repeating units of GlcNAc-MurNAc or MurNAc-GlcNAc (Figure 1). The disaccharides MurNAc-GlcNAc and GICNAc-MurNAc with dipeptides were previously synthesized ${ }^{[14]}$ but not clear differences in the immunostimulatory activities of the compounds were observed. Peptidoglycan fragments with more than two MurNAc-GIcNAc repeating units have not previously been synthesized; therefore, we investigated the biological activities of such synthetic fragments by testing their innate immunostimulatory activities through the intercellular receptor, Nod2. This study reports the first synthesis of tetrasaccharide fragments, particularly compounds contain- 
A)

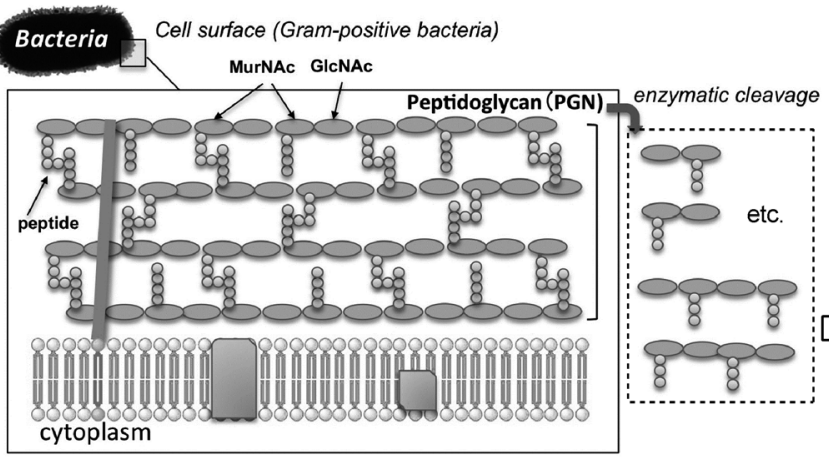

B)

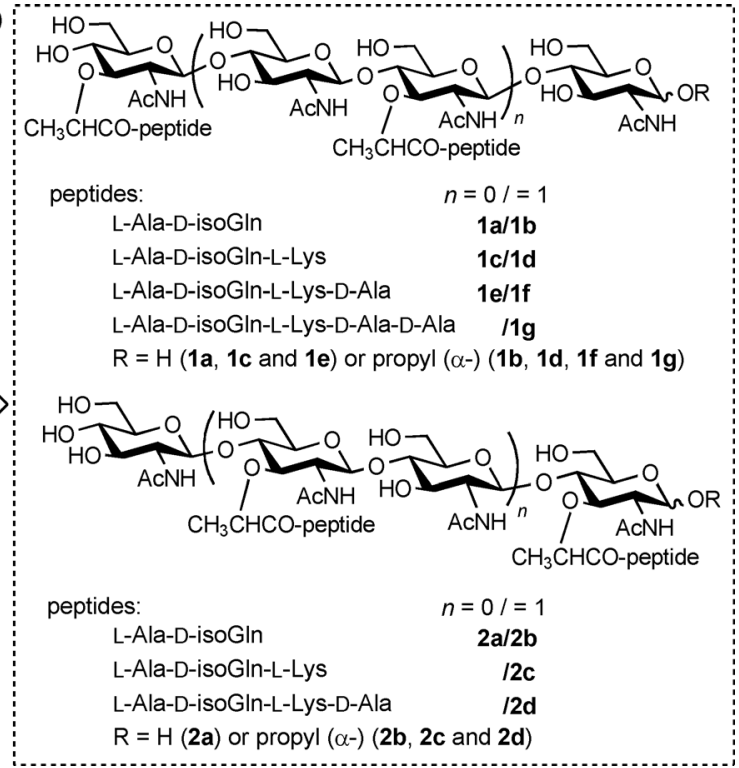

Figure 1. A) Cell surface of a Gram-positive bacterium and schematic diagram of the enzymatic cleavage of the cell-wall component, peptidoglycan. B) A PGN fragment library containing two types of glycan sequence.

ing MurNAc-GlcNAc repeating units. The activities of the tetrasaccharide-containing PGN fragments, as well as the di- and monosaccharide-containing fragments, were systematically investigated in human Nod2 (hNod2) for the first time.

\section{Results and Discussion}

\section{Synthesis of peptidoglycan fragment library}

Syntheses of PGN fragments have been reported previously, including by us. ${ }^{[5,6]}$ In our studies, 2-N-Troc (Troc: 2,2,2-trichloroethoxycarbonyl) protection was used for both the glycosyl donor and acceptor for the glycosylation of glucosamine (GlcN) and muramic acid (MurN) in the synthesis of the complex PGN fragments. ${ }^{[10,11]} \mathrm{A}$ high $\beta$-selectivity was obtained with neighboring group participation of the $N$-Troc group. The glycosyl acceptor 4 showed a higher reactivity than the $\mathrm{N}$-acetylated acceptors. In our latest study, we applied the same $\mathrm{N}$ Troc protection strategy. We also examined the leaving groups in the donors: trichloroacetimidate $\mathrm{e}^{[10,15]}$ and $\mathrm{N}$-phenyltrifluoroacetimidate. ${ }^{[16]} \mathrm{N}$-phenyltrifluoroacetimidate showed good reactivity toward glycosylation at the 4-OH group in the MurNTroc residue, as shown below.

The repeating glycans in compounds $\mathbf{1} \mathbf{a}-\mathbf{1} \mathbf{g}$ (Figure $1 \mathrm{~B}$ ) were constructed by preparing the key disaccharide glucosaminyl$\beta(1 \rightarrow 4)$-muramic acid intermediate $\mathbf{5}$, as shown in Scheme 1 , based on methods developed previously in our group. ${ }^{[10,11]} \beta$ Selective glycosylation with the
$\mathrm{N}$-Troc-muramyl trichloroacetimidate donor 3 of the $\mathrm{N}$-Trocglucosaminyl acceptor $\mathbf{4}$ was carried out in the presence of catalytic amounts of trimethylsilyl trifluoromethanesulfonate (TMSOTf) as the activator to afford the disaccharide $\mathbf{5}$ in high yield (84\%).

The disaccharide analogues were then synthesized from $\mathbf{5}$, as illustrated in Scheme 2. Cleavage of the Troc groups of $\mathbf{5}$ with $\mathrm{Zn} / \mathrm{Cu}$ in $\mathrm{AcOH}$ and subsequent acetylation with $\mathrm{Ac}_{2} \mathrm{O}$ gave compound 6 . The allyl group was isomerized to a vinyl group by using $\mathrm{H}_{2}$-activated $\left[\operatorname{lr}(\mathrm{cod})\left(\mathrm{MePh}_{2} \mathrm{P}\right)_{2}\right] \mathrm{PF}_{6}(\mathrm{cod}=1,5$-cyclooctadiene) to give compound 7 , and cleavage of the ethyl ester with $\mathrm{LiOH}$ gave 8 . The appropriate peptides were introduced to the liberated carboxylic acid 8 by using 1-ethyl-3-(3dimethylaminopropyl)carbodiimide hydrochloride ("water-soluble carbodiimide", WSCD.HCl), 1-hydroxybenzotriazole (HOBt), and triethylamine (TEA). The vinyl group was then cleaved with iodine and $\mathrm{H}_{2} \mathrm{O}$, and hydrogenation with $\mathrm{Pd}(\mathrm{OH})_{2}$ successfully gave the disaccharide fragments $1 \mathrm{a}, 1 \mathrm{c}$, and $1 \mathrm{e}$.

Tetrasaccharide $\mathbf{1 2}$ was then synthesized by using $\mathbf{5}$ as a common synthetic intermediate for both the glycosyl donor 


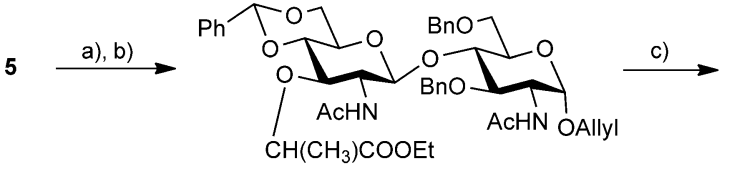

6

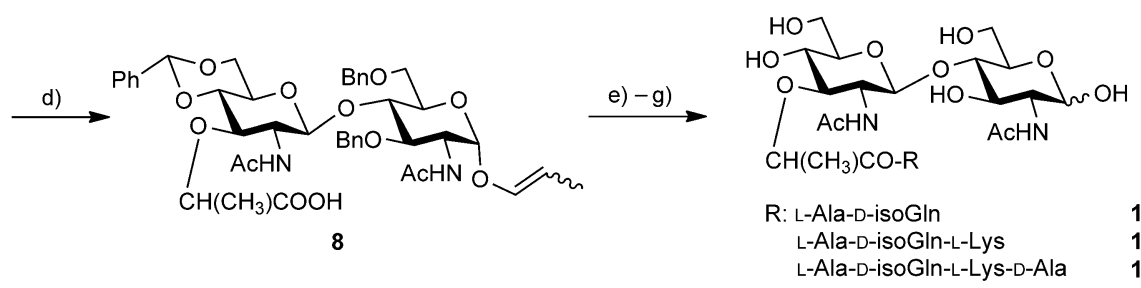

$9 a$

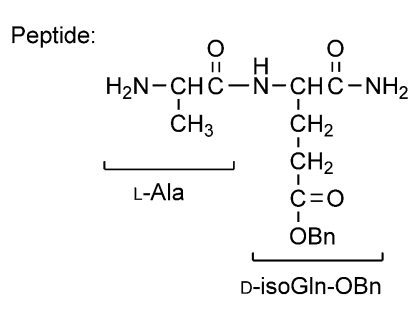

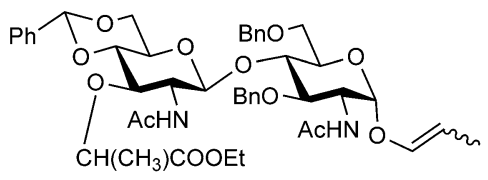

7

a (from 9a)

1c (from 9b)

1e (from 9c)
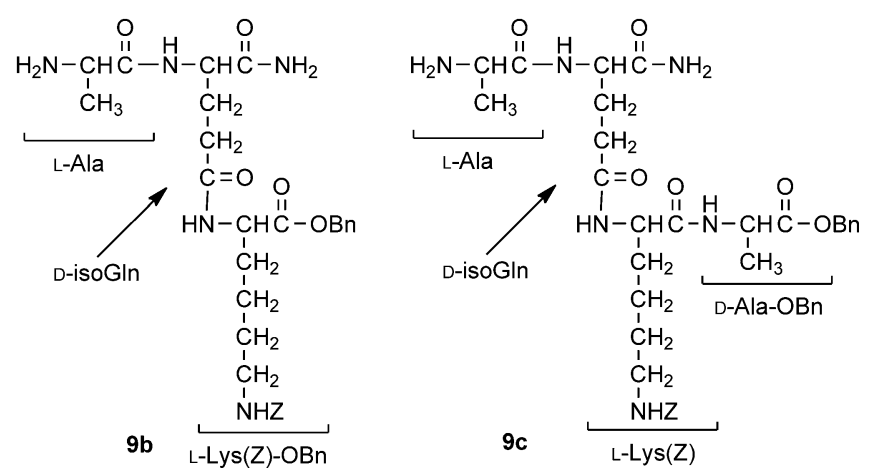

Scheme 2. Synthesis of the PGN disaccharide fragments $1 \mathrm{a}, 1 \mathrm{c}$, and 1 e. a) $\left.\mathrm{Zn} / \mathrm{Cu}, \mathrm{AcOH}, 30 \mathrm{~min} ; \mathrm{b}) \mathrm{Ac} \mathrm{C}_{2} \mathrm{O} / \mathrm{Py}, 1 \mathrm{~h}, 74 \%(2 \mathrm{steps}) ; \mathrm{c}\right)\left[\mathrm{Ir}(\mathrm{cod}) \mathrm{H}\left(\mathrm{MePh} \mathrm{P}_{2} \mathrm{P}\right.\right.$ ] $\mathrm{PF}$; THF, 1.5 h, 68\%; d) LiOH, dioxane/THF/ $\mathrm{H}_{2} \mathrm{O}$ (2:4:1), quant; e) $9 \mathrm{a}, \mathbf{9 b}$ and $9 \mathrm{c}$, WSCD.HCl/HOBT/TEA DMF, $72 \%$ (with $9 \mathrm{a}$ ), $59 \%$ (with 9 b) or $48 \%$ (with $9 \mathrm{c}$ ); f) $\mathrm{I}_{2} / \mathrm{H}_{2} \mathrm{O}, 64,54,64 \%$, respectively; g) $\mathrm{H}_{2} / \mathrm{Pd}(\mathrm{OH})_{2}, \mathrm{AcOH}, 91 \%$ (1 a), $89 \%$ (1 c), $90 \%$ (1 e).

and acceptor (Scheme 3). The disaccharide donors 10a and $10 \mathrm{~b}$ were prepared through cleavage of the allyl glycoside and subsequent conversion to their imidate forms (10a: trichloroacetimidate, $10 \mathrm{~b}$ : $\mathrm{N}$-phenyltrifluoroacetimidate). Regioselective reductive ring opening of the $4^{\prime}, 6^{\prime}$-O-benzylidene of 5 was carried out by using $\mathrm{BH}_{3} \cdot \mathrm{Me}_{3} \mathrm{~N}$ and $\mathrm{BF}_{3} \cdot \mathrm{Et}_{2} \mathrm{O}$ in $\mathrm{CH}_{3} \mathrm{CN}^{[17]}$ to afford the disaccharide glycosyl acceptor 11 with a free 4-hydroxy group in $83 \%$ yield. For the preparation of the tetrasaccharide 12, the trichloroacetimidate 10 a was first used as the glycosyl donor in a coupling reaction with the glycosyl acceptor $11 ; i^{[11]}$ however, glycosylation between $10 \mathrm{a}$ and 11 in the presence of TMSOTf as a Lewis acid gave the desired tetrasaccharide 12 only in $16 \%$ yield, with a $62 \%$ recovery of 11 . An increase in the reaction temperature or changes in the equivalents of reactants did not improve the yield. Possible reasons for the low yield include: 1) The 4-OH group of the disaccharide acceptor $\mathbf{1 1}$ has a low reactivity due to steric hindrance from the 3-O-lactyl moiety in the muramic acid residue; 2 ) trichloroacetimidate $10 \mathrm{a}$ is highly reactive, but the activated cationic intermediate decomposes prior to the desired glycosylation because attack of $\mathbf{1 1}$ on the intermediate is sterically encumbered.

We then used the $N$-phenyltrifluoroacetimidate ${ }^{[16]} 10 \mathrm{~b}$ as the glycosyl donor. Generally, glycosyl N-phenyltrifluoroacetimidates are also highly reactive but show better stabilities than the corresponding trichloroacetimidates. The formation of $\mathrm{N}$ - glycosyl trifluoroacetamides as by-products is suppressed because the $N$-phenyl group of the eliminated $N$-phenyltrifluoroacetamide prevents the undesirable attack of the amide on the cationic intermediates. Glycosylation by $\mathrm{N}$-phenyltrifluoroacetimidate $10 \mathrm{~b}$ was promoted by increasing the equivalent of acceptor 11 (donor/acceptor ratio 1:1.5). The glycosylation yield when using acceptor 11 improved dramatically to $61 \%$ of tetrasaccharide 12.

Removal of the $N$-Troc groups from the amino groups at the 2-positions of 12, $\mathrm{N}$-acetylation of the liberated amino groups, and saponification of the ethyl esters produced the dicarboxylic acid 13 with a tetrasaccharide MGMG (MurNAc-GlcNAc) sequence. The glycan backbone 13 was then coupled to di-, tri-, tetra-, and pentapeptides by using condensation reagents in DMF. Condensation of 13 with $\mathrm{HCl} \cdot \mathrm{L}-\mathrm{Ala}-\mathrm{D}-\mathrm{isoG} \ln (\mathrm{OBn})$ and $\mathrm{HCl} \cdot \mathrm{L}-\mathrm{Ala}$-D-isoGln-L-Lys(Z)(OBn) was effected by using WSCD, $\mathrm{HOBt}$, and triethylamine to give the protected tetrasaccharide containing two units of dipeptide $\mathbf{1 4}$ in $82 \%$ yield and the tripeptide 15 in $53 \%$ yield. Condensation of the longer peptide was achieved by using $O$-(7-azabenzotriazol-1-yl)- $N, N, N^{\prime}, N^{\prime}$-tetramethyluronium hexafluorophosphate (HATU) as a coupling reagent along with triethylamine to obtain higher yields; this resulted in a tetrasaccharide with tetrapeptides, 16, in $81 \%$ yield and a tetrasaccharide with pentapeptides, 17 , in $71 \%$ yield. All benzyl and benzylidene groups were then removed to obtain PGN fragments of tetrasaccharides having di-, tri-, 

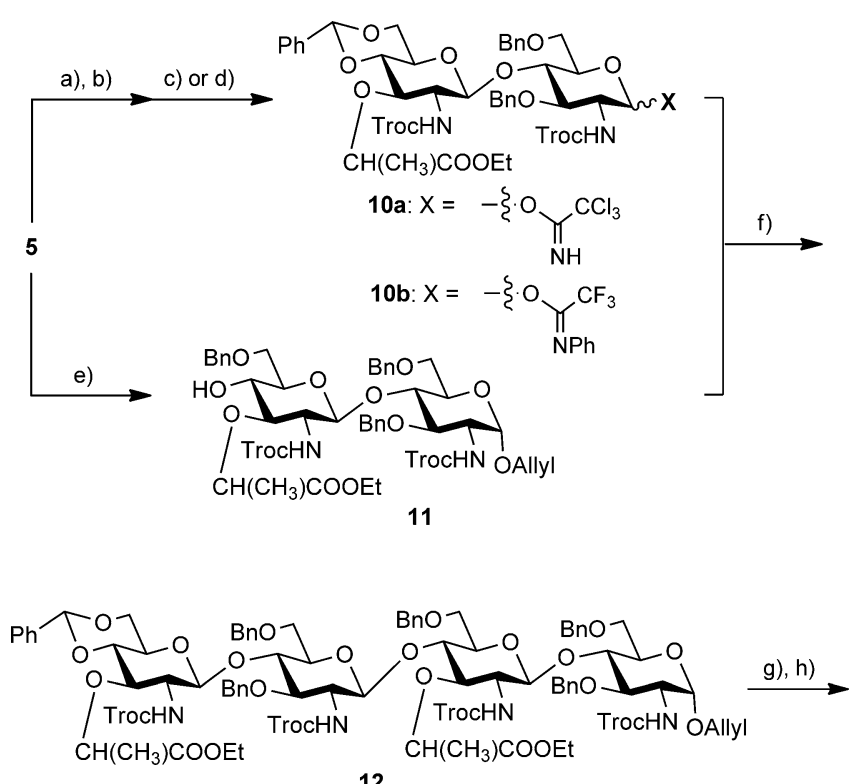

12

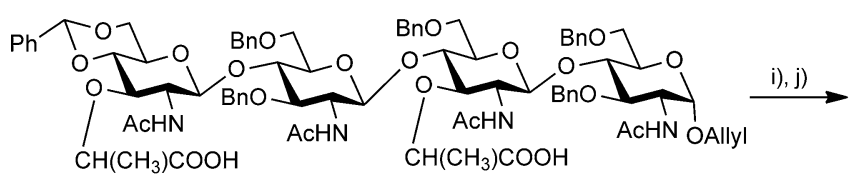

13

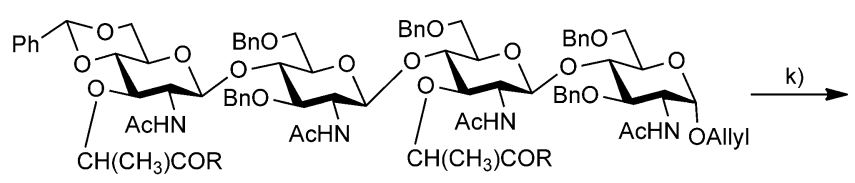

$$
R=\begin{array}{ll}
\text { L-Ala-D-isoGln(OBn) } & 14: 82 \% \\
\text { L-Ala-D-isoGln-L-Lys(Z)(OBn) } & 15: 53 \% \\
\text { L-Ala-D-isoGIn-L-Lys(Z)-D-Ala(OBn) } & 16: 81 \% \\
\text { L-Ala-D-isoGln-L-Lys(Z)-D-Ala-D-Ala(OBn) } & 17: 71 \%
\end{array}
$$

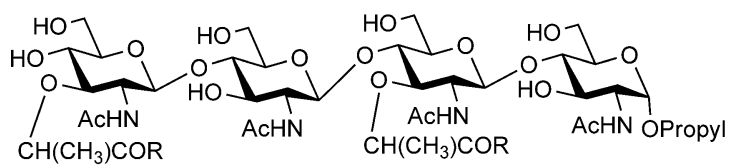

$$
R=\begin{array}{lr}
\text { L-Ala-D-isoGln } & \text { 1b: } 89 \% \\
\text { L-Ala-D-isoGIn-L-Lys } & \text { 1d: } 67 \% \\
\text { L-Ala-D-isoGIn-L-Lys-D-Ala } & \text { 1f: } 38 \% \\
\text { L-Ala-D-isoGIn-L-Lys-D-Ala-D-Ala } & \text { 1g: } 45 \%
\end{array}
$$

Scheme 3. Synthesis of PGN tetrasaccharide fragments. a) $[\mathrm{Ir}(\operatorname{cod}) \mathrm{H}-$ $\left.\left(\mathrm{MePh}_{2} \mathrm{P}\right)_{2}\right] \mathrm{PF}_{6}, \mathrm{THF}, 1.5 \mathrm{~h}$; b) $\mathrm{I}_{2} / \mathrm{H}_{2} \mathrm{O}, 30 \mathrm{~min}, 81 \%$; c) $\mathrm{CCl}_{3} \mathrm{CN} / \mathrm{Cs}_{2} \mathrm{CO}_{3}, \mathrm{CH}_{2} \mathrm{Cl}_{2}$, 30 min, quant. (10 a); d) $\mathrm{CF}_{3}(\mathrm{NPh}) \mathrm{Cl} / \mathrm{Na}_{2} \mathrm{CO}_{3}$, acetone, 3 days, $76 \%(10 \mathrm{~b})$; e) $\mathrm{Me}_{3} \mathrm{~N} \mathrm{BH}_{3} / \mathrm{BF}_{3} \cdot \mathrm{Et}_{2} \mathrm{O}, \mathrm{CH}_{3} \mathrm{CN}, 1 \mathrm{~h}, 83 \%$; f TMSOTf, $\mathrm{CH}_{2} \mathrm{Cl}_{2},-15^{\circ} \mathrm{C}, 4 \AA$ molecular sieves, $40 \mathrm{~min}, 16 \%$ (from $10 \mathrm{a}$ ) or $61 \%$ (from $10 \mathrm{~b}$ ); g) $\mathrm{Zn} / \mathrm{Cu}, \mathrm{AcOH}$, $3 \mathrm{~h}, \mathrm{Ac}_{2} \mathrm{O} / \mathrm{Py}, 2 \mathrm{~h}, 62 \%$; h) LiOH, quant.; Condensation: i) WSCD/HOBt/DMF/ TEA, HCl-L-Ala-D-isoGln(OBn) (for 14) or HCl-L-Ala-D-isoGln-L-Lys(Z)(OBn) (for 15); j) HATU/DMF/TEA, HCl-L-Ala-D-isoGln-L-Lys(Z)-D-Ala(OBn) (for 16) or $\mathrm{HCl} \cdot \mathrm{L}-A l a-D-i s o G I n-L-L y s(Z)-D-A l a-D-A l a(O B n)$ (for 17); k) $\mathrm{H}_{2} / \mathrm{Pd}(\mathrm{OH})_{2}, \mathrm{AcOH}$. tetra-, or pentapeptides (1 $\mathbf{b}, \mathbf{1} \mathbf{d}, \mathbf{1} \mathbf{f}$, or $\mathbf{1} \mathbf{g}$, respectively). In order to compare the biological activities of the two kinds of glycan sequence, PGN fragments with the disaccharide GIcNAc-MurNAc units, such as a disaccharide with a dipeptide (2 a) or a tetrasaccharide with di-, tri-, or tetrapeptide $(\mathbf{2} \mathbf{b}, \mathbf{2} \mathbf{c}$, or $\mathbf{2} \mathbf{d}$, respectively) as shown in Figure 1, were also synthesized according to the previously reported methods. ${ }^{[1]]}$

\section{Human Nod2 stimulation with PGN fragments in a glycan- sequence-dependent manner}

The hNod2 stimulatory activity of each synthetic PGN fragment was then evaluated by using hNod2-transfected HEK293T cells, with NF- $\kappa \mathrm{B}$ activation determined by using a luciferase reporter assay, as described previously. ${ }^{[18]}$ As shown in Figure $2 \mathrm{~A}$, the synthesized tetrasaccharides containing PGN fragments $(\mathbf{1} \mathbf{b}$, $\mathbf{1 d}, \mathbf{1} \mathbf{f}, \mathbf{1} \mathbf{g}$, and $\mathbf{2} \mathbf{b}-\mathbf{2} \mathbf{d}$ ) were compared with the monosac-
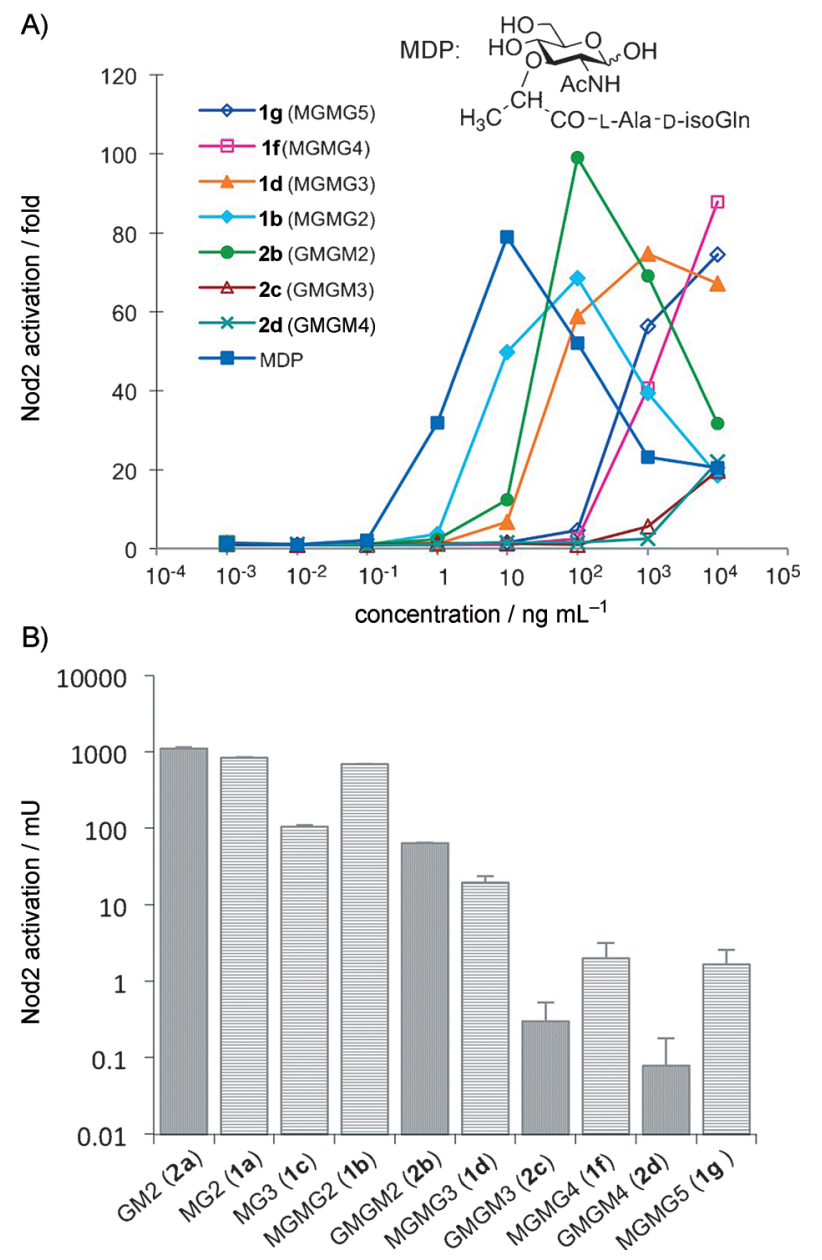

Figure 2. Stimulation of hNod2 by the synthesized PGN fragments. A) Dosedependent hNod2 activation by the chemically synthesized tetrasaccharide containing PGN fragments, in comparison to a monosaccharide-dipeptide (MDP). B) hNod2 activation by the chemically synthesized disaccharide- and tetrasaccharide-containing PGN fragments at concentrations of $1 \mathrm{ng} \mathrm{mL}^{-1}$. A Nod2 activation of $1000 \mathrm{mU}$ is equal to the activation of MDP at $1 \mathrm{ng} \mathrm{mL}^{-1}$. HEK293T cells were transfected with $h N O D 2$, and the indicated amount of each compound was added to the cells. The ability of each compound to activate NF- $\kappa B$ was determined by using a luciferase reporter assay. ${ }^{[18]}$ 
charide dipeptide MDP in a dose-dependent manner. In both glycan sequences, the tetrasaccharide compounds with dipeptide (L-Ala-D-isoGln; $\mathbf{1} \mathbf{b}$ and $\mathbf{2} \mathbf{b}$ ) exhibited stronger activities than the same glycan sequence groups with longer peptide chains. The dependence on peptide length was consistent with previous results. ${ }^{[11]}$ Interestingly, differences in the glycan sequence caused significant differences in hNod2 activation, and the MurNAc-GICNAc (MG)-containing sequence displayed more potent activity than the GICNAc-MurNAc (GM) sequence. Among the dipeptide-containing fragments, MGMG2 (1 b) showed stronger activity than GMGM2 (2 b) at concentrations of 1 and $10 \mathrm{ng} \mathrm{mL}^{-1}$. GMGM3 (2 c) and GMGM4 (2 d) exhibited only very weak activation even at higher concentrations (1000 and $10000 \mathrm{ng} \mathrm{mL}^{-1}$ ), but MGMG3 (1 d) and MGMG4 (1 f) showed much stronger hNod2 activation.

Figure $2 \mathrm{~B}$, shows the $\mathrm{hNod} 2$ activities of the disaccharides ( $1 \mathrm{a}, \mathbf{1} \mathrm{c}$, and $\mathbf{2 a}$ ), and also the tetrasaccharide fragments ( $1 \mathrm{~b}$, $\mathbf{1 d}, \mathbf{1} \mathbf{f}, \mathbf{1} \mathbf{g}$, and $\mathbf{2} \mathbf{b}-\mathbf{2} \mathbf{d}$ ) obtained at concentrations of $1 \mathrm{ng} \mathrm{mL}^{-1}$. Among the PGN fragments, the disaccharides with dipeptides, $\mathbf{1} \mathrm{a}$ and $\mathbf{2} \mathrm{a}$, showed potent activities comparable to the activation of the monosaccharide dipeptide, MDP. In these cases, it was not clear that the differences in glycan sequence affected hNod2 activation. Among the tetrasaccharide fragments, the activity clearly depended on the glycan sequence, and compounds with the MGMG sequence exhibited higher hNod2 activation than those containing the GMGM sequence, all other aspects of the peptide structures being the same. The hNod2 stimulatory abilities of the two types of glycan sequence differed significantly in the tetrasaccharide case: MGMG2 (1 b) had an approximately tenfold higher activity than GMGM2 (2 b); MGMG3 (1 d) had an approximately 65fold higher activity than GMGM3 (2c); and MGMG4 (1 f) had an approximately 26-fold higher activity than GMGM4 (2d).

In this research, we have revealed major differences between the hNod2 innate immunostimulatory activities of peptidoglycan fragments having one of two types of glycan sequence. The MGMG (MurNAc-GICNAc) 2 sequences (obtained through cleavage by $\mathrm{N}$-acetylglucosaminidase) showed much stronger hNod2 activities than GMGM (GlcNAc-MurNAc) 2 sequences (cleaved by muramidase, including lysozyme), for a given peptide structure.

\section{Conclusions}

We have described the preparation of various PGN fragments containing alternating glycan disaccharide or tetrasaccharide sequences and a series of peptide chains, from di- to pentapeptides in good overall yields. The sequential glycosylation method provided an efficient approach to the divergent synthesis of PGN fragment structures with repeating glycan patterns. The chemically synthesized PGN fragments were tested for their hNod2 stimulatory activities. The results suggest that hNod2 activation by PGN fragments depends on the circumstances under which the PGN glycan is enzymatically cleaved, that is, by $\mathrm{N}$-acetylglucosaminidase or muramidase. The results suggest that differences in the bacterial PGN degradation or construction enzymes (glycan cleaving enzymes or the peptidases) might affect immunomodulation in humans.

\section{Experimental Section}

Synthesis of the tetrasaccharide fragments: Compounds and spectroscopic data not described below are provided in the Supporting Information.

Glycosylation for the preparation of the tetrasaccharide intermediate 12 (from $10 \mathrm{~b})$ : TMSOTf $(5 \mu \mathrm{L}, 0.03 \mathrm{mmol})$ was added to a mixture of the imidate $10 \mathrm{~b}(135 \mathrm{mg}, 0.11 \mathrm{mmol})$, the acceptor 11 (200 mg, $0.18 \mathrm{mmol}$ ), and MS4A $4 \AA$ molecular sieves in dry $\mathrm{CH}_{2} \mathrm{Cl}_{2}$ $(20 \mathrm{~mL})$ at $-15^{\circ} \mathrm{C}$. After the mixture had been stirred at the same temperature for $20 \mathrm{~min}$, the reaction was quenched with chilled sat. aq. $\mathrm{NaHCO}_{3}(10 \mathrm{~mL})$, and the mixture was extracted with $\mathrm{CHCl}_{3}$ $(50 \mathrm{~mL})$. The organic layer was washed with sat. aq. $\mathrm{NaHCO}_{3}$ $(20 \mathrm{~mL})$ and brine $(20 \mathrm{~mL})$, dried over $\mathrm{Na}_{2} \mathrm{SO}_{4}$, and concentrated in vacuo. The residue was purified by silica gel chromatography (30 g, toluene/EtOAc 7:1) to give 12 as a colorless solid (141 mg, $61 \%)$. ${ }^{1} \mathrm{H}$ NMR $\left(\mathrm{CDCl}_{3}, 500 \mathrm{MHz}\right): \delta=7.45-7.18(\mathrm{~m}, 30 \mathrm{H}), 5.85-5.82$ $(\mathrm{m}, 2 \mathrm{H}), 5.41(\mathrm{~s}, 1 \mathrm{H}), 5.24-5.12(\mathrm{~m}, 3 \mathrm{H}), 4.88-4.59(\mathrm{~m}, 14 \mathrm{H}), 4.50-$ $4.10(\mathrm{~m}, 13 \mathrm{H}), 4.02-3.87(\mathrm{~m}, 7 \mathrm{H}), 3.77(\mathrm{~m}, 1 \mathrm{H}), 3.67-3.49(\mathrm{~m}, 8 \mathrm{H})$, $3.40-3.38(\mathrm{~m}, 3 \mathrm{H}), 3.25(\mathrm{t}, J=10.0 \mathrm{~Hz}, 1 \mathrm{H}), 3.17(\mathrm{brs}, 1 \mathrm{H}), 3.06(\mathrm{~d}$, $J=10.0 \mathrm{~Hz}, 1 \mathrm{H}), 2.97-2.94(\mathrm{~m}, 2 \mathrm{H}), 1.38(\mathrm{~d}, J=7.0 \mathrm{~Hz}, 3 \mathrm{H}), 1.29-$ $1.24 \mathrm{ppm}(\mathrm{m}, 9 \mathrm{H}) ;{ }^{13} \mathrm{C} \mathrm{NMR}\left(\mathrm{CDCl}_{3}, 125 \mathrm{MHz}\right): \delta=175.6,173.9$, $155.9,155.5,154.3,154.0,139.5,138.9,138.1,137.8,137.6,137.2$, $133.5,129.5,129.1,129.1,128.6,128.5,128.4,128.4,128.3,128.2$, $128.1,127.9,127.8,127.6,127.4,127.3,127.1,125.9,117.9,102.8$, $101.8,100.2,96.6,96.0,95.6,95.5,82.4,80.4,78.2,77.7,75.0,74.8$, $74.6,74.5,74.3,74.1,74.0,73.4,73.9,70.8,68.4,68.4,68.0,67.5$, $65.7,61.2,61.1,57.5,57.3,57.0,54.7,18.8,18.4,14.2,14.1$ ppm; HRMS (ESI-QTOF MS): calcd for $\mathrm{C}_{91} \mathrm{H}_{104} \mathrm{Cl}_{12} \mathrm{~N}_{4} \mathrm{O}_{29} \mathrm{~K}$ : 2175.2686 $[M+\mathrm{K}]^{+}$, found: 2175.2556 .

Tetrasaccharide 13: $\mathrm{Zn} / \mathrm{Cu}$ (prepared from $500 \mathrm{mg}$ of $\mathrm{Zn}$ ) was added to a solution of 12 (200 mg, $0.09 \mathrm{mmol})$ in AcOH $(2 \mathrm{~mL})$, and the mixture was stirred at room temperature for $30 \mathrm{~min}$. The insoluble materials were filtered off, and the filtrate was concentrated in vacuo. The residual solvent was removed by coevaporation with toluene $(10 \mathrm{~mL})$. The residue was dissolved in pyridine $(2 \mathrm{~mL})$ and acetic anhydride $(2 \mathrm{~mL})$, and the solution was stirred at room temperature for $1 \mathrm{~h}$. The reagents were removed by concentration with toluene $(10 \mathrm{~mL})$. The residue was purified by silica gel chromatography $\left(50 \mathrm{~g}, \mathrm{CHCl}_{3} /\right.$ acetone 9:1) to give 2- $\mathrm{N}$-acetyl tetrasaccharide as a white solid (93 mg, 62\%). ' $\mathrm{H} N \mathrm{NMR}\left(\mathrm{CDCl}_{3}\right.$, $400 \mathrm{MHz}): \delta=7.44-7.21(\mathrm{~m}, 31 \mathrm{H}), 6.98(\mathrm{~m}, 1 \mathrm{H}), 6.74(\mathrm{~d}, J=6.8 \mathrm{~Hz}$, $1 \mathrm{H}), 6.07(\mathrm{~d}, J=8.4 \mathrm{~Hz}, 1 \mathrm{H}), 5.81(\mathrm{~m}, 1 \mathrm{H}), 5.47(\mathrm{~s}, 1 \mathrm{H}), 5.24-5.14$ $(\mathrm{m}, 3 \mathrm{H}), 4.95(\mathrm{~d}, J=12.8 \mathrm{~Hz}, 1 \mathrm{H}), 4.84(\mathrm{~d}, J=3.6 \mathrm{~Hz}, 1 \mathrm{H}), 4.74-4.64$ $(\mathrm{m}, 5 \mathrm{H}), 4.55-4.45(\mathrm{~m}, 5 \mathrm{H}), 4.36-4.02(\mathrm{~m}, 14 \mathrm{H}), 3.96-3.38(\mathrm{~m}, 20 \mathrm{H})$, $3.23(\mathrm{t}, J=9.6 \mathrm{~Hz}, 1 \mathrm{H}), 3.13(\mathrm{~m}, 1 \mathrm{H}), 3.05(\mathrm{~m}, 1 \mathrm{H}), 1.98(\mathrm{~s}, 3 \mathrm{H}), 1.94$ $(\mathrm{s}, 3 \mathrm{H}), 1.88(\mathrm{~s}, 3 \mathrm{H}), 1.78(\mathrm{~s}, 3 \mathrm{H}), 1.37(\mathrm{~d}, J=6.8 \mathrm{~Hz}, 3 \mathrm{H}), 1.31-$ $1.21 \mathrm{ppm}(\mathrm{m}, 9 \mathrm{H}) ;{ }^{13} \mathrm{C} \mathrm{NMR}\left(\mathrm{CDCl}_{3}, 125 \mathrm{MHz}\right): \delta=175.9,174.7$, 172.4, 172.3, 171.8, 169.8, 139.6, 138.8, 138.3, 138.1, 138.1, 138.0, $137.2,133.7,129.1,128.5,128.3,128.3,128.2,128.2,128.0,127.9$, $127.8,127.7,127.4,127.3,127.2,125.9,117.5,102.4,101.1,100.8$, $100.5,96.3,95.5,82.6,80.3,76.4,75.8,75.4,74.9,74.6,74.1,73.8$, 73. $4,73.4,73.2,72.8,71.1,68.5,68.5,68.2,68.0,65.9,61.3,61.0$, $55.4,55.0,53.4,52.1,29.7,29.3,23.9,23.6,23.5,23.4,23.1,18.8$, 18.6, 14.2, $14.1 \mathrm{ppm}$; HRMS (ESI-QTOF MS): calcd for $\mathrm{C}_{87} \mathrm{H}_{108} \mathrm{~N}_{4} \mathrm{O}_{25} \mathrm{Na}: 1631.7200[\mathrm{M}+\mathrm{Na}]^{+}$, found: 1631.7169 .

$\mathrm{LiOH}(16 \mathrm{mg}, 0.7 \mathrm{mmol}$ ) was added to a solution of 2- $\mathrm{N}$-acetyl tetrasaccharide $(93 \mathrm{mg}, 0.06 \mathrm{mmol})$ in dioxane $/ \mathrm{THF} / \mathrm{H}_{2} \mathrm{O} \quad(2: 4: 1$, 
$4.0 \mathrm{~mL}$ ), and the mixture was stirred at room temperature for $1 \mathrm{~h}$. The solution was neutralized with Dowex $\mathrm{H}^{+}$(Dowex $50 \mathrm{~W} \times 8$ 200-400 mesh $\mathrm{H}$ form, Dow Chemicals), then applied to an HP-20 column $(2 \mathrm{~cm} \times 10 \mathrm{~cm})$. Organic and inorganic salts were removed by elution with $\mathrm{H}_{2} \mathrm{O}(160 \mathrm{~mL})$, followed by elution with $\mathrm{MeOH}$ and concentration in vacuo to give a tetrasaccharide with a free lactic acid moiety, 13, as a white solid (89 mg, quant). ' $\mathrm{H}$ NMR $\left(\mathrm{CD}_{3} \mathrm{OD}\right.$, $400 \mathrm{MHz}): \delta=7.34-6.99(\mathrm{~m}, 30 \mathrm{H}), 5.83(\mathrm{~m}, 1 \mathrm{H}), 5.40(\mathrm{~s}, 1 \mathrm{H}), 5.20$ (dd, $J=17.6,1.6 \mathrm{~Hz}, 1 \mathrm{H}), 5.09-5.00(\mathrm{~m}, 2 \mathrm{H}), 4.84(\mathrm{~d}, J=11.2 \mathrm{~Hz}$, $1 \mathrm{H}), 4.68(\mathrm{~d}, J=3.6 \mathrm{~Hz}, 1 \mathrm{H}), 4.60-4.37(\mathrm{~m}, 8 \mathrm{H}), 4,25-4.21(\mathrm{~m}, 3 \mathrm{H})$, 4.09-4.00 (m, 2H), 3.95-3.31 (m, 22 H), 3.04-2.95 (m, 2H), $1.89(\mathrm{~m}$, $6 \mathrm{H}), 1.77(\mathrm{~s}, 6 \mathrm{H}), 1.31-1.19 \mathrm{ppm}(\mathrm{m}, 6 \mathrm{H})$; HRMS (ESI-QTOF MS): calcd for $\mathrm{C}_{83} \mathrm{H}_{100} \mathrm{~N}_{4} \mathrm{O}_{25} \mathrm{Na}$ : $1575.6574[\mathrm{M}+\mathrm{Na}]^{+}$, found: 1575.6508 .

Tetrasaccharide dipeptide backbone 14: WSCD.HCl $(8 \mathrm{mg}$, $0.048 \mathrm{mmol})$ and triethylamine $(15 \mu \mathrm{L}, 0.096 \mathrm{mmol})$ were added at $0{ }^{\circ} \mathrm{C}$ to a solution of $13(25 \mathrm{mg}, 0.016 \mathrm{mmol}), \mathrm{HCl} \cdot$-L-Ala-D-isoGln$\mathrm{OBn}(22 \mathrm{mg}, 0.064 \mathrm{mmol})$, and $\mathrm{HOBt}(7 \mathrm{mg}, 0.048 \mathrm{mmol})$ in DMF $(3 \mathrm{~mL})$, and the mixture was stirred at RT overnight. The mixture was concentrated, and the residue was dissolved in $\mathrm{CHCl}_{3}$. The solution was washed with citric acid $(1 \mathrm{M}, 20 \mathrm{~mL}), \mathrm{H}_{2} \mathrm{O}(20 \mathrm{~mL})$, sat. aq. $\mathrm{NaHCO}_{3}(20 \mathrm{~mL})$, and brine $(20 \mathrm{~mL})$. The organic layer was dried over $\mathrm{Na}_{2} \mathrm{SO}_{4}$, and concentrated in vacuo. The residue was purified by silica gel chromatography $\left(5 \mathrm{~g}, \mathrm{CHCl}_{3} / \mathrm{MeOH} 15: 1\right)$ to give 14 as a white solid (28 mg, 82\%). ${ }^{1} \mathrm{H}$ NMR ([D] $\left.] \mathrm{DMF}, 400 \mathrm{MHz}\right): \delta=8.12-$ $8.04(\mathrm{~m}, 3 \mathrm{H}), 7.85(\mathrm{~d}, J=9.2 \mathrm{~Hz}, 1 \mathrm{H}), 7.68-7.00(\mathrm{~m}, 48 \mathrm{H}), 5.90(\mathrm{~m}$ $1 \mathrm{H}), 5.70(\mathrm{~s}, 1 \mathrm{H}), 5.14(\mathrm{dd}, J=17.2,1.9 \mathrm{~Hz}, 1 \mathrm{H}), 5.08-5.17(\mathrm{~m}, 6 \mathrm{H})$, $4.95(\mathrm{~d}, J=11.2 \mathrm{~Hz}, 1 \mathrm{H}), 4.84(\mathrm{~d}, J=8.4 \mathrm{~Hz}, 1 \mathrm{H}), 4.76(\mathrm{~d}, J=3.7 \mathrm{~Hz}$, $1 \mathrm{H}), 4.64-4.29(\mathrm{~m}, 15 \mathrm{H}), 4.20-3.57(\mathrm{~m}, 24 \mathrm{H}), 3.25-3.15(\mathrm{~m}, 3 \mathrm{H})$, $2.49(\mathrm{t}, J=8.0 \mathrm{~Hz}, 4 \mathrm{H}), 2.31-2.20(\mathrm{~m}, 2 \mathrm{H}), 1.86-1.77(\mathrm{~m}, 14 \mathrm{H}), 1.29-$ $1.20 \mathrm{ppm}(\mathrm{m}, 12 \mathrm{H}) ;{ }^{13} \mathrm{C}$ NMR ([D $\left.7 \mathrm{DMF}, 100 \mathrm{MHz}\right): \delta=173.9,173.9$, $173.3,173.2,173.1,173.0,170.8,170.8,170.1,140.7,140.4,139.8$, 139.7, 139.6, 138.7, 137.3, 137.3, 135.3, 129.4, 129.1, 128.9, 128.7, $128.6,138.5,128.2,128.2,128.1,128.0,127.9,127.8,127.4,126,7$, $116,9,101.8,101.3,97.5,92.9,81.6,80.2,80.0,79.8,79.6,77.2,75.3$, 74.5, 73.0, 72.9, 71.0, 69.2, 68.8, 68.5, 66.7, 66.3, 53.3, 52.8, 50.0, $49.6,36.0,31.0,28.0,23.7,23.6,23.4,22.8,19.4,19.2,18.3$, $17.7 \mathrm{ppm}$; HRMS (ESI-QTOF MS): calcd for $\mathrm{C}_{113} \mathrm{H}_{138} \mathrm{~N}_{10} \mathrm{O}_{31} \mathrm{Na}_{2}$ : $1088.4662[\mathrm{M}+2 \mathrm{Na}]^{2+}$, found: 1088.4655 .

Tetrasaccharide tetrapeptide backbone 16: HATU (11 mg, $0.019 \mathrm{mmol})$ and triethylamine $(8 \mu \mathrm{L}, 0.039 \mathrm{mmol})$ were added at $0{ }^{\circ} \mathrm{C}$ to a solution of $13(15 \mathrm{mg}, 0.006 \mathrm{mmol})$ and HCl.L-Ala-DisoGln-L-Lys(Z)-D-Ala-OBn (19 mg, $0.019 \mathrm{mmol})$ in DMF (3 mL), and the mixture was stirred at RT overnight. The mixture was concentrated, and the residue was dissolved in $\mathrm{CHCl}_{3}$. The solution was washed with citric acid $(1 \mathrm{M}, 20 \mathrm{~mL}), \mathrm{H}_{2} \mathrm{O}(20 \mathrm{~mL})$, sat. aq. $\mathrm{NaHCO}_{3}$ $(20 \mathrm{~mL})$, and brine $(20 \mathrm{~mL})$. The organic layer was dried over $\mathrm{Na}_{2} \mathrm{SO}_{4}$ and concentrated in vacuo. The residue was purified by silica gel chromatography $\left(5 \mathrm{~g}, \mathrm{CHCl}_{3} / \mathrm{MeOH} 15: 1\right)$ to give 16 as a white solid (23 mg, 81\%). ${ }^{1} \mathrm{H}$ NMR $\left(\mathrm{CDCl}_{3} / \mathrm{CD}_{3} \mathrm{OD} 4: 1,500 \mathrm{MHz}\right.$ ) $\delta=7.41-7.21(\mathrm{~m}, 50 \mathrm{H}), 5.85(\mathrm{~m}, 1 \mathrm{H}), 5.43(\mathrm{~s}, 1 \mathrm{H}), 5.25-5.06(\mathrm{~m}$, $8 \mathrm{H}), 4.93-4.81(\mathrm{~m}, 2 \mathrm{H}), 4.68-4.25(\mathrm{~m}, 16 \mathrm{H}), 4.13-3.89(\mathrm{~m}, 11 \mathrm{H})$, 3.47-3.36 $(\mathrm{m}, 11 \mathrm{H}), 3.12(\mathrm{~m}, 4 \mathrm{H}), 2.35-2.18(\mathrm{~m}, 6 \mathrm{H}), 2.02-1.79(\mathrm{~m}$, $14 \mathrm{H}), 1.48-1.10 \mathrm{ppm}(\mathrm{m}, 30 \mathrm{H})$; HRMS (ESI-QTOF MS): calcd for $\mathrm{C}_{147} \mathrm{H}_{184} \mathrm{~N}_{16} \mathrm{O}_{39} \mathrm{Na}_{2}: 1421.6351[\mathrm{M}+2 \mathrm{Na}]^{2+}$, found: 1421.6357.

Deprotection of the tetrasaccharide dipeptide $1 \mathrm{~b}$ : Palladium hydroxide $(55 \mathrm{mg})$ in $\mathrm{AcOH}$ was added to a solution of 14 (28 mg, $0.013 \mathrm{mmol})$ in $\mathrm{AcOH}(1 \mathrm{~mL})$, and the mixture was stirred under $\mathrm{H}_{2}$ $(2 \mathrm{MPa})$ for one day. The reaction was monitored by TLC, and the hydrogenolysis was continued until deprotection was complete. The Pd catalyst was filtered off by using celite, and the filtrate was concentrated. The residue was lyophilized from acetonitrile $/ \mathrm{H}_{2} \mathrm{O}$ to give 1 b $(16.6 \mathrm{mg}, 89 \%)$ as a white solid. ${ }^{1} \mathrm{H} N M R \quad\left(\mathrm{CD}_{3} \mathrm{OD}\right.$,
$500 \mathrm{MHz}): \delta=4.81-4.25(\mathrm{~m}, 9 \mathrm{H}), 3.87-3.29(\mathrm{~m}, 26 \mathrm{H}), 2.38(\mathrm{brs}, 4 \mathrm{H})$, 2.19 (brs, 2H), $1.97(\mathrm{~m}, 14 \mathrm{H}), 1.60-1.58(\mathrm{~m}, 2 \mathrm{H}), 1.43-1.34(\mathrm{~m}$, $12 \mathrm{H}), 0.95-0.91 \mathrm{ppm}(\mathrm{dd}, J=12.0,7.0 \mathrm{~Hz}, 3 \mathrm{H}) ;{ }^{13} \mathrm{C}$ NMR $\left(\mathrm{CD}_{3} \mathrm{OD}\right.$, $125 \mathrm{MHz}): \delta=176.3,175.9,175.6,175.2,175.2,173.9,173.9,173.8$, 173.5, 103.3, 103.1, 101.8, 98.2, 83.4, 81.9, 81.6, 80.0, 78.7, 78.4, 78.0, 77.4, 76.8, 76.0, 73.9, 72.2, 71.2, 70.9, 70.8, 62.5, 62.0, 61.6, $61.4,57.0,56.4,55.9,55.1,53.9,53.8,50.7,49.6,31.6,28.8,28.4$, 23.7, 23.4, 22.5, 19.5, 18.9, 17.7, 17.5, 11.0 ppm; HRMS (ESI-QTOF MS): calcd for $\mathrm{C}_{57} \mathrm{H}_{94} \mathrm{~N}_{10} \mathrm{O}_{31} \mathrm{Na}$ : $1437.5984[\mathrm{M}+\mathrm{Na}]^{+}$, found: 1437.6008 .

1 c-1 g were similarly synthesized. 1 c: ${ }^{1} \mathrm{H}$ NMR $\left(\mathrm{D}_{2} \mathrm{O}, 500 \mathrm{MHz}\right): \delta=$ $5.11(\mathrm{~d}, J=2.6 \mathrm{~Hz}, 1 \mathrm{H}), 4.49(\mathrm{~d}, J=8.5 \mathrm{~Hz}, 1 \mathrm{H}), 4.27$ (dd, $J=9.5$, $4.5 \mathrm{~Hz}, 1 \mathrm{H}), 4.22-4.13(\mathrm{~m}, 2 \mathrm{H}), 3.87-3.44(\mathrm{~m}, 14 \mathrm{H}), 3.32-3.26(\mathrm{~m}$, $3 \mathrm{H}), 2.47-2.32(\mathrm{~m}, 2 \mathrm{H}), 2.15-1.88(\mathrm{~m}, 8 \mathrm{H}), 1.36-1.29(\mathrm{~m}, 7 \mathrm{H}), 1.11-$ $1.00 \mathrm{ppm}(\mathrm{m}, 5 \mathrm{H}) ;{ }^{13} \mathrm{C}$ NMR $\left(\mathrm{D}_{2} \mathrm{O}, 150 \mathrm{MHz}\right): \delta=178.9,175.9,175.6$, 175.1, 174.5, 174.2, 174.0, 101.3, 94.8, 90.4, 82.5, 79.7, 78.2, 75.6, $78.2,75.6,74.6,72.5,70.0,69.3,68.7,61.3,60.6,60.1,54.9,53.6$, 49.7, 39.3, 31.9, 31.1, 27.0, 26.3, 27.0, 26.3, 22.2, 22.1, 21.9, 18.8, $16.6 \mathrm{ppm}$; HRMS (ESI-QTOF): calcd for $\mathrm{C}_{33} \mathrm{H}_{57} \mathrm{~N}_{7} \mathrm{O}_{17} \mathrm{Na}: 846.3709$ $[\mathrm{M}+\mathrm{Na}]^{+}$, found: 846.3697 .

$1 \mathrm{~d}$ : ${ }^{1} \mathrm{H}$ NMR $\left(\mathrm{D}_{2} \mathrm{O}, 400 \mathrm{MHz}\right): \delta=4.40-4.35(\mathrm{~m}, 2 \mathrm{H}), 4.26(\mathrm{~m}, 1 \mathrm{H})$, 4.10-4.03 (m, 5H), 3.79-3.20 (m, $29 \mathrm{H}), 2.84(\mathrm{t}, J=7.0 \mathrm{~Hz}, 4 \mathrm{H}), 2.26-$ $2.24(\mathrm{~m}, 4 \mathrm{H}), 2.07-2.03(\mathrm{~m}, 2 \mathrm{H}), 1.90-1.80(\mathrm{~m}, 14 \mathrm{H}), 1.66(\mathrm{~m}, 2 \mathrm{H})$, 1.58-1.51 (m, 6H), 1.43-1.39 (m, 2H), 1.31-1.21 (m, 16 H), $0.74 \mathrm{ppm}$ $\left(\mathrm{t}, J=7.4 \mathrm{~Hz}, 3 \mathrm{H}\right.$ ); HRMS (ESI-QTOF MS): calcd for $\mathrm{C}_{69} \mathrm{H}_{119} \mathrm{~N}_{14} \mathrm{O}_{33} \mathrm{~K}$ : $855.3851[\mathrm{M}+\mathrm{H}+\mathrm{K}]^{2+}$, found: 855.3832 .

1 e: ${ }^{1} \mathrm{H}$ NMR ( $\left.\mathrm{D}_{2} \mathrm{O}, 500 \mathrm{MHz}\right): \delta=5.06(\mathrm{~d}, J=3.0 \mathrm{~Hz}, 1 \mathrm{H}), 4.44(\mathrm{~d}, J=$ $8.0 \mathrm{~Hz}, 1 \mathrm{H}), 4.20-4.02(\mathrm{~m}, 5 \mathrm{H}), 3.82-3.38(\mathrm{~m}, 12 \mathrm{H}), 2.86(\mathrm{t}, J=$ $7.5 \mathrm{~Hz}, 2 \mathrm{H}), 2.31-2.28(\mathrm{~m}, 2 \mathrm{H}), 2.04(\mathrm{~m}, 1 \mathrm{H}), 1.91(\mathrm{~s}, 3 \mathrm{H}), 1.86-1.82$ $(\mathrm{m}, 4 \mathrm{H}), 1.74-1.62(\mathrm{~m}, 4 \mathrm{H}), 1.32-1.30(\mathrm{~m}, 5 \mathrm{H}), 1.25(\mathrm{~d}, J=6.3 \mathrm{~Hz}$, $3 \mathrm{H}), 1.19 \mathrm{ppm}(\mathrm{d}, J=7.3 \mathrm{~Hz}, 3 \mathrm{H})$; HRMS (ESI-QTOF): calcd for $\mathrm{C}_{36} \mathrm{H}_{63} \mathrm{~N}_{8} \mathrm{O}_{18}: 895.4260[\mathrm{M}+\mathrm{H}]^{+}$, found: 895.4213 .

$1 \mathrm{f}:{ }^{1} \mathrm{H}$ NMR $\left(\mathrm{D}_{2} \mathrm{O}, 400 \mathrm{MHz}\right): \delta=4.39-4.37(\mathrm{~m}, 3 \mathrm{H}), 4.25-4.22(\mathrm{~m}$, $2 \mathrm{H}), 4.17-4.10(\mathrm{~m}, 8 \mathrm{H}), 3.76-3.15(\mathrm{~m}, 26 \mathrm{H}), 2.85(\mathrm{t}, J=7.2 \mathrm{~Hz}, 4 \mathrm{H})$, $2.28-2.26(\mathrm{~m}, 4 \mathrm{H}), 2.07-2.03(\mathrm{~m}, 2 \mathrm{H}), 1.90-1.80(\mathrm{~m}, 14 \mathrm{H}), 1.63-1.52$ $(\mathrm{m}, 10 \mathrm{H}), 1.44-1.42(\mathrm{~m}, 2 \mathrm{H}), 1.31-1.17(\mathrm{~m}, 20 \mathrm{H}), 0.74(\mathrm{t}, J=7.4 \mathrm{~Hz}$, $3 \mathrm{H})$; HRMS (ESI-QTOF MS): calcd for $\mathrm{C}_{75} \mathrm{H}_{129} \mathrm{~N}_{16} \mathrm{O}_{35} \mathrm{Na}$ : 918.4352 $[\mathrm{M}+\mathrm{H}+\mathrm{Na}]^{2+}$, found: 918.4310 .

$1 \mathrm{~g}:{ }^{1} \mathrm{H}$ NMR $\left(\mathrm{D}_{2} \mathrm{O}, 400 \mathrm{MHz}\right): \delta=4.43-4.38(\mathrm{~m}, 2 \mathrm{H}), 4.30-4.06(\mathrm{~m}$, $11 \mathrm{H}), 3.88-3.25(\mathrm{~m}, 28 \mathrm{H}), 2.87(\mathrm{t}, J=7.6 \mathrm{~Hz}, 4 \mathrm{H}), 2.29-2.26(\mathrm{~m}, 4 \mathrm{H})$ 2.09-2.01 (m, 2H), 1.92-1.82 (m, 14H), 1.67-1.53 (m, 8H), 1.48-1.41 $(\mathrm{m}, 2 \mathrm{H}), 1.33-1.24(\mathrm{~m}, 28 \mathrm{H}), 0.77(\mathrm{t}, J=7.6 \mathrm{~Hz}, 3 \mathrm{H})$; HRMS (ESIQTOF MS): calcd for $\mathrm{C}_{81} \mathrm{H}_{140} \mathrm{~N}_{18} \mathrm{O}_{37}: 978.4813[M+2 \mathrm{H}]^{2+}$, found: 978.4783.

HEK293T bioassay for human Nod2 activity: Ligand-dependent NF- $\kappa B$ activation was determined by using $0.5 \times 10^{5}$ HEK293T cells transfected with expression plasmids of Nod2 (33 ng of pMX2HANod2) in the presence of reporter plasmids, NF- $\mathrm{kB}$-dependent pBxIV-luc, and control pEF1BOS- $\beta$-Gal, as described. ${ }^{[3]}$ Briefly, HEK293T cells were transfected with expression plasmids by the calcium phosphate method. Eight hours post-transfection, the cells were treated with medium containing a synthesized ligand. 24 hours post-transfection, ligand-dependent NF- $\kappa B$ activation was determined by using a luciferase reporter assay. ${ }^{[18]}$

\section{Acknowledgements}

This work was supported in part by Grants-in-Aid for Scientific Research from the Japan Society for the Promotion of Science 
(nos. 23.1965, 19310144, 20241053, and 22310136), by grants from the Institute for Fermentation, Osaka (IFO), the Suntory Institute for Bioorganic Research (SUNBOR Grant), the Houansha Foundation, the Takeda Science Foundation, the Naito Foundation, the Japan Chemical Innovation and Inspection Institute, Osaka University's Global COE program (Frontier Biomedical Science Underlying Organelle Network Biology), and a funding program for Next Generation World-Leading Researchers (NEXT Program; LR025) from JSPS and CSTP.

Keywords: compound libraries - glycosylation • Nod2 peptidoglycans

11] N. Inohara, Y. Ogura, A. Fontalba, O. Gutierrez, F. Pons, J. Crespo, K. Fukase, S. Inamura, S. Kusumoto, M. Hashimoto, S. J. Foster, A. P. Moran, J. L. Fernandez-Luna, G. Nuñez, J. Biol. Chem. 2003, 278, 5509-5512.

[2] S. E. Girardin, I. G. Boneca, J. Viala, M. Chamaillard, A. Labigne, G. Thomas, D. J. Philpott, P. J. Sansonetti, J. Biol. Chem. 2003, 278, 88698872.

[3] M. Chamaillard, M. Hashimoto, Y. Horie, J. Masumoto, S. Qiu, L. Saab, Y. Ogura, A. Kawasaki, K. Fukase, S. Kusumoto, M. A. Valvano, S. J. Foster T. W. Mak, G. Nuñez, N. Inohara, Nat. Immunol. 2003, 4, 702-707.

[4] S. E. Girardin, I. G. Boneca, L. A. Carneiro, A. Antignac, M. Jehanno, J. Viala, K. Tedin, M. K. Taha, A. Labigne, U. Zahringer, A. J. Coyle, P. S. DiStefano, J. Bertin, P. J. Sansonetti, D. J. Philpott, Science 2003, 300, 1584-1587

[5] Y. Fujimoto, A. R. Pradipta, N. Inohara, K. Fukase, Nat. Prod. Rep. 2012 29, 568-579.

[6] Y. Fujimoto, S. Inamura, A. Kawasaki, Z. Shiokawa, A. Shimoyama, T. Hashimoto, S. Kusumoto, K. Fukase, J. Endotoxin Res. 2007, 13, 189-196.
[7] Y. Ogura, D. K. Bonen, N. Inohara, D. L. Nicolae, F. F. Chen, R. Ramos, H. Britton, T. Moran, R. Karaliuskas, R. H. Duerr, J. P. Achkar, S. R. Brant, T. M Bayless, B. S. Kirschner, S. B. Hanauer, G. Nuñez, J. H. Cho, Nature 2001, 411, 603-606

[8] J. P. Hugot, M. Chamaillard, H. Zouali, S. Lesage, J. P. Cezard, J. Belaiche, S. Almer, C. Tysk, C. A. O'Morain, M. Gassull, V. Binder, Y. Finkel, A. Cortot, R. Modigliani, P. Laurent-Puig, C. Gower-Rousseau, J. Macry, J. F. Colombel, M. Sahbatou, G. Thomas, Nature 2001, 411, 599-603.

[9] C. Vignal, E. Singer, L. Peyrin-Biroulet, P. Desreumaux, M. Chamaillard, Microbes Infect. 2007, 9, 658-663.

[10] S. Inamura, K. Fukase, S. Kusumoto, Tetrahedron Lett. 2001, 42, 7613 7616.

[11] S. Inamura, Y. Fujimoto, A. Kawasaki, Z. Shiokawa, E. Woelk, H. Heine, B. Lindner, N. Inohara, S. Kusumoto, K. Fukase, Org. Biomol. Chem. 2006, 4, $232-242$.

[12] Y. Fujimoto, Y. Konishi, O. Kubo, M. Hasegawa, N. Inohara, K. Fukase, Tetrahedron Lett. 2009, 50, 3631-3634.

[13] A. Kawasaki, Y. Karasudani, Y. Otsuka, M. Hasegawa, N. Inohara, Y. Fujimoto, K. Fukase, Chem. Eur. J. 2008, 14, 10318-10330.

[14] S. Kusumoto, K. Yamamoto, M. Imoto, M. Inage, M. Tsujimoto, S. Kotani, T. Shiba, Bull. Chem. Soc. Jpn. 1986, 59, $1411-1417$.

[15] R. R. Schmidt, J. Michel, Angew. Chem. 1980, 92, 763-764; Angew. Chem. Int. Ed. Engl. 1980, 19, $731-732$.

[16] B. Yu, H. Tao, Tetrahedron Lett. 2001, 42, 2405-2407.

[17] M. Oikawa, W. C. Liu, Y. Nakai, S. Koshida, K. Fukase, S. Kusumoto, Synlett 1996, 1179-1180

[18] M. Hasegawa, K. Yang, M. Hashimoto, J. H. Park, Y. G. Kim, Y. Fujimoto, G. Nuñez, K. Fukase, N. Inohara, J. Biol. Chem. 2006, 281, 29054-29063.

Received: October 11, 2012

Published online on January 29, 2013 